DOI: $10.31866 / 2410-1915.20 .2019 .172439$

УДК 7.01:008

\title{
СИНТЕЗ МИСТЕЦТВ У СЕЗОНАХ СЕРГІЯ ДЯГІЛЄВА ЯК ДІАЛОГ КУЛЬТУР: ПОСТРЕАЛЬНІСТЬ ІНТЕРПРЕТАТИВНИХ ПАРАДИГМ
}

\section{Ареф’єва Анна Юріївна}

Кандидат філософських наук, ORCID: 0000-0003-4619-9281, anna.arefieva@i.ua, Національний педагогічний університет імені М. П. Драгоманова, вул. Пирогова, 9, Київ, Україна, 02000

У статті аналізується осмислення культури в рамках глобалізації культурного потенціалу в цілому та своєрідним синтезом, синкрезами і інтенціональними процесами формують всезагальний культурно-історичний потенціал, що потребує своєї інтерпретації в мистецтві. У цьому контексті досвід сезонів С. Дягілєва свідчить про саму суть культури як динамічну цілісність. Цей образ був пріоритетним не лише на початку XX ст., так й до сьогодні залишається актуальним.

Метою статті є визначення взаємодії у художніх творах, що ставилися у сезонах С. Дягілєва як синтез мистецтв та діалог культур.

У дослідженні використано інтенціональний метод, який дав можливість виявити і дослідити акти свідомості, які беруть участь в осмисленні реальності С. Дягілєва. Крім того, використані компаративний та системний підходи. Компаративний підхід дає можливість провести порівняльний аналіз різних феноменів культури, стилів та жанрів, видів мистецтв в контексті їх виникнення. Системний та полісистемний підхід дає можливість визначити принципи холізму (домінанти системи) та антихолізму (домінанти частини системи) як можливість знаходження феноменів культурних практик в різних системних конфігураціях: соціальних, ідеологічних, рекламних, віртуальних та ін.

Наукова новизна полягає в тому, що кінець XX - початок XXI ст. у сезонах С.Дягілєва визначені в контексті певної культурологічної авторефлексії, коли століття тому виникали події, які нині іменуються «глобалізаційними». У той час вони визначались як урбанізаційні, трансформативні, інтегративні. Величезне значення в цьому контексті має той факт, що формувались творчі колективи на межі культурних інституцій, які утворювали новітню реальність культуротворення.

Висновки. Доведено, що синтез мистецтв неможливий без діалогу культур, а діалог неможливий без синтезу. Культура певним чином є мистецтвом, яке є культурою. Ця глибинна тотожність мистецтва 3 культурою свідчить про те, що і та, й інша реальність, якщо ії̈ пов'язують з образотворчим потенціалом (естетичним, етичним, антропологічним та ін.), характеризується як вмінням, майстерністю, творчістю, креативністю, які свідчать про духовний потік потенціалу людяності як духовного виміру у своїх абсолютних ознаках.

Ключові слова: культура; діалог культур; мистецтво; синтез мистецтв; образ; ідеал.

(C) Ареф’єва А. Ю., 2019 


\section{Вступ}

Осмислення культури в новітніх рамках, які пов’язані з глобалізацією культурного потенціалу в цілому, глобалізацією як своєрідним синтезом, синкрезами і своєрідними інтенціональними (лат. Intentio - намір, прагнення) процесами, які формують всезагальний культурно-історичний потенціал, що потребує своєї інтерпретації в мистецтві. Ця нерозривна єдність культури та мистецтва свідчить про те, що власне категорія «діалог» вже неспроможна описати всі процеси культуротворчості. Діалог як комунікативний та естетичний феномен, за М. Бахтіним, стає одним із найголовніших принципів апеляції до іншої людини, іншої культури, адже визначення очима іншого (Великого іншого - Бога, Абсолюту), очима культури, іншого мистецтва, інших вподобань, інших поетик, естетик ще не вирішує проблеми синтезу мистецтв. За будь-яким діалогом стоїть монолог та феномен розсіювання, який орієнтований на абсолют, на віру у чудо, у диво (Бахтин, 1963).

Вивчаючи онтологічну концепцію діалогізму М. Бахтіна, яка є основою діалогічної стратегії у розгляді проблеми Іншого (Бахтин, 1963), можемо зауважити, що онтологія М. Бахтіна пронизана ідеєю діалогізму, яка відображається у вислові самого автора: «Бути - значить спілкуватися діалогічно» (Бахтин, 1963, с. 338). Відповідно до цієї комунікативної концепції людське буття полягає у нескінченному діалозі з Ти або Іншим. Людина бере участь у цьому нескінченному діалозі всім своїм єством протягом усього свого життя. Розглядаючи діалог культур, можемо використати цитату послідовника Бахтіна В. С. Біблера. Феномен культури «проникає .... у всі головні події життя та свідомість людей нашого часу» (Біблер, 1990, с. 261). Бахтін зазначає про відсутність кордонів у культурних явищах: «Кожний культурний процес відбувається саме на кордоні: у цьому виражається всі його значимість і сутність, якщо він віддаляється від кордонів, то втрачає грунт, на якому базується, стає пусткою, занепадає і вмирає» (Бахтин, 1975, с. 25). С.Дягілєв у своїй творчій діяльності дотримувався принципу діалогізму, діалогу між людьми, культурами, країнами і народами, акцентуючи увагу на взаємозбагаченні культур (Бочкарева, 1971).

Еквівалентність, подібність масштабів завдань, образних трансформацій свідчить про те, що звернення до таких потужних імпульсів культуротворчості, які пов'язані з культурними інституціями, зокрема 3 досвідом сезонів С. Дягілєва, стає не просто інтепретативним простором, реаліями, схемами, системами, коридорами або маркерами чи форматами мислення сьогоднішніх процесів глобалізації, адже свідчать про саму суть культури як динамічну цілісність. Цей образ був пріоритетним як на початку XX ст., так й до сьогодні залишається актуальним.

Проблема синтезу мистецтв є однією із важливих питань у сучасній історіографії. Зокрема, В. Бичков та ін. досліджували актуальні проблеми сучасної естетики та філософії мистецтва (Бычков, 2012). Де основну увагу 
приділено питання про місце естетики в сучасному світі та метафізичні й екзистенціальні аспекти естетики і мистецтва. А. Зісь вивчав дизайн мультимедійних проектів, пов'язаних з мистецтвом живопису (Зись, 1978) В. Фаворський досліджує теорію художнього формоутворення (Фаворский, 1988) та ін. Однак, малодослідженим залишається контест хореографічних, театральних, музичних синетез кінця XIX - початку XX ст., зокрема у сезонах С. Дягілєва.

Окремо можемо назватидослідження з музики,денизка робіт пов'язана 3 творами О. Лосєва, Б. Асаф’єва, Є. Назайкінського, Ю. Холопова та інш. Дослідження 3 хореографії - це роботи, які об'єднані з дослідженнями В. Гаєвського та ін. дослідників, які багато додали щодо реконструкції образів хореографії у В. Ніжинського, Г. Баланчина, С. Сліфаря, М. Бежера.

Сценографічний синтез мистецтв достатньо плідно досліджувався в роботах, пов’язаних з театральною культурою. Це дослідження І. Костіної й багатьох інших науковців. До нашого завдання не входить називати їх тут, вони аналізуються у окремих розділах дослідження. Головне визначити художній синтез як певну поліфонію взаємодії різних жанрів та видів мистецтв як синтез міжкультурних взаємодій. Отже, взаємообумовленість мистецтв є одним процесом, який не можна розчленувати, визначити якісь пріоритетні засади - чи то культурні, чи то мистецькі - бо вони в певній мірі $є$ еквівалентними, бо і мистецтво, і культура мають один корінь.

Мистецтво функціонує не як соціологічний феномен, не як продуцент образів, не як ескалація образного поля або образотворчих інтенцій образних можливостей, мистецтво функціонує як проектно-моделюючий підхід, засобами якого визначається цінність людини, культури і взагалі художня діяльність людини в цілому. Цей підхід надзвичайно гостро піднімається в сьогоднішніх дослідженнях, які поєднують візуальні та віртуальні, вербальні імплікації в межах пошуку певної метамови - мови спільнот (віртуальних, комунікативних, які формуються в сьогоднішніх реаліях комунікації, що утворюють нові реалії комунікації). Виникає симультанна постать того суб’єкта, хто створює інформацію, приймає іï, корегує і доводить до певних, естетичних ознак.

Цей контекст, звичайно, по різному осмислюється. Поп-культура, масова культура, дизайн, реклама, мода й інші сьогоднішні механізми інститутилізації мистецтв свідчать про те, що формується новий синтез, але вся його новизна вписується в ранжир засобів і технологій традиції, а внутрішні глибинні інтенції, які дають образний потенціал, націлені на ті важливі образи синтезу мистецтв, які $є$ діалогом, $є$ одночасно культуротворчістю і образом спільної творчості.

Пошуки іншого «Я», іншої людини, іншого, як абсолюту, існування поблизу абсолюта, чуда, як еквівакація (осмислення з позиції абсолюту та позиції профанного світу) свідчить про те, що культура як поле формотворчості і мистецтво, як верхівка творчого, естетичного потенціалу культуротворчості завжди є діалогом. 


\section{Мета статті}

Метою статті $є$ визначення взаємодії у художніх творах, що ставилися у сезонах С. Дягілєва як синтез мистецтв та діалог культур. Досвід синтезу мистецтв у сезонах С.Дягілєва дозволив проаналізувати аксіологічні, рефлексивні, антропологічні, семіологічні та візуальні контексти в рамках культорогенезу як мистецького синтезу; визначити принципи діалогу та розповсюдження, як парадигми глобалізації культури, зокрема в контексті синтезу мистецтв; охарактеризувати синтетизм та синкретизм еволюції мистецтв як засоби культуротворчості; надати системний аналіз хореїчності європейського мистецтва як системи жанрового, видовищного, музичного та хореографічного синтезу в мистецтві; охарактеризувати досвід ентерпрези та продюсерської діяльності С. Дягілєва як певну систему режисерської роботи 3 опосередкуючої діяльності в контексті діалогу культур та синтезу мистецтв; визначити чинники музичних синтез сезонів Дягілєва в контексті міфопоетики, неокласики та авангардної музики, пов'язаною зі стилістикою, французьким музичним імпресіонізмом, а також діяльністю провідних акторів музичного простору, зокрема I. Стравінським, М. Римським-Корсаковим, С. Прокофієвим тощо, а також визначити вплив їх творчості на розвиток музичних синтез XX ст.

У дослідженні використано інтенціональний метод, який дав можливість виявити і дослідити акти свідомості, які беруть участь в осмисленні реальності С. Дягілєва. Крім того, використані компаративний та системний підходи. Компаративний підхід дає можливість порівняльного аналізу різних феноменів культури, стилів та жанрів, видів мистецтв у контексті їх виникнення. Системний та полісистемний підхід дає можливість визначити принципи холізму (домінанти системи) та антихолізму (домінанти частини системи) як можливість знаходження феноменів культурних практик в різних системних конфігураціях: соціальних, ідеологічних, рекламних, віртуальних та ін.

\section{Виклад матеріалу дослідження}

Наприкінці XIX - початку XX ст. художня культура трансформувалася в межах стилю модерн, авангарду, а пізніше постмодерну. XXI ст. уже не має таких гострих трансформативних спонук, але розпочалося осмислення досвіду модерну та постмодерну вже в рамках інших реалій культурного топосу, який можна називати всезагальним у контексті мультикультуралізму й глобалізації культури, що аж ніяк не зводиться до процесу інтеграції засобів й типів формотворення, а говорить про те, що людство шукає новітню поетику, образну систему та новітні надсистемні регулятиви осмислення власного «я» в нескінченному просторі всесвіту. Усе це свідчить про те, що традиційний синтез мистецтв доповнює одні явища (діалогізми, взаємодії, трансформативності, мімезису) іншими (віртуалістикою, арт-бізнесом, шоу-бізнесом, тотальною інтерактивність мистецтва), а це ті образні, конфігуративні, поетичні, естетичні реалії, 
які визначають певну диференціацію, або певний диспозитив (протиставленням спонук), який стає транспозитивом за М. Фуко (Фуко, 2014), (переходом з однієї позиції на іншу, транспозицією, за М. Бахтіним як набуття досвіду іншого та збагачення новітнім баченням світу, збагачення іншим буттям як естетичним досвідом іншого (Бахтин, 1975).

У рамках художнього досвіду, який стає феноменом артизації сучасної культури, моделювання мистецьких процесів надзвичайно важливими $€$ композиційні, диспозиційні, транспозиційні ознаки культуротворення. Це дає можливість не лише гармонізації і пошуку консенсусу, образних паритетів та культурних ніш для усвідомлення екомайбутнього, перспективи розвитку та розуміння необхідності індивідуального обличчя кожного актора глобалізаційних процесів, але свідчить про те, що синтез не може бути самодостатнім арт-феноменом. Він завжди має зворотній бік, пов’язаний з диференціацією мистецта, а культурологія стає диференційною метатеорією розвитку індивідуальності та синтезу мистецтв. Так, синтетичне бачення світу формує систему механізмів культуротворчості як системне надбання і всезагальну систематику мистецького синтезу.

Відтак, антихолізм бачення цілого дозволяє позбутися редукціонізму, тотальної гомогенності, що виникає у всіх новітніх спокусах за доби глобалізації. Постулюється гетерохронія як багатовимірність часу, існування образних феноменів у будь-якому іншому часі й вимірі культури (час завжди є циклічним - це час-вічність, це час-стріла, що походить від християнства, що дає можливість поліфонічного бачення художнього образу у різних еонах), а також гетеротопія - існування в різних просторових конфігураціях, просторових культурних еонах, тобто обжитих, засвоєних як мистецька цілісність культури. Отже, гетерохронія та гетеротопія керелюють з гомогенізацією, тим що можна назвати - виникненням антисистеми, антисистемних рухів (реформацій, андеграунду, нонконформізму), які так чи інакше свідчать про цілісність мистецтва як поліфонічного, багатовимірного явища, орієнтованого на те, що людина завжди рефлектує над цілісністю культури, формує образ світу як образ іншого «я», культури, буття, як гармонійну, поліфонічну завершену художню реальність.

3 позиції рефлексійних підходів, вважається, що у XX ст. маркер моди на дослідження або певних орієнтацій направлений на ті повороти, які визначають як антологічний, антропологічний, а також семіологічний, що скерований на лінгвістику, візуальний поворот. Так, за таким підходом, поворот стає одним 3 рефлексивних системотворчих, більше того, інтерпретативних підходів. Це свідчить про те, що в системі рефлексійних вимірів дослідники шукають інші засади, інші витоки, намагаються моделювати ситуацію, якби вона вже існувала в іншому просторі, в іншому часі, розвивалася б іншим шляхом. Якби, наприклад, авангард не був перерваний тоталітаризмом, то чим би це закінчилось? Якби тоталітаризм не було знищено, то чим би це закінчилось в культурі? Усі ці модельні реконструкції-підходи стають рефлективними культурологічними синтезами, а мистецтво тут постає одним із найголовніших принципів 
формування модельного підходу, який допомагає реконструювати тотальність культури людського «я», тотальність мистецтва як певну тоталогію.

Рефлексія 3 середини практики пов'язана 3 фахом, 3 фаховою належністю, професіоналізмом, відповідальністю за свій цех. Рефлексія над практикою - філософська, культурологічна, мистецтвознавча та будьяка інша - починає порівнювати всі рефлексивні системи у плані здатності вирішувати, відповідати, інтерпретувати ті чи інші реалії в евристичному полі змагального простору тієї рефлексії, що визначає глибинні витоки культуротворчості як можливість нового поштовху або повороту.

\section{Висновки}

Отже, рефлексія в інше, якщо згадати феноменологію Гегеля, стає одним із важливих тотальних або тоталітарних підходів, які в системі глобалізації культури має екстенсивну метрику засвоєння, вподобання, асиміляції, якщо не колонізації культури. Утім, рефлексія в себе, зосередження на своєму прагрунті, своїх внутрішніх мотивах, системах можливості саморозвитку культурно-історичного потенціалу стає протилежною екстенсивному типу, діалогу взаємодій, свідчить про інтенсифікацію духовності, духовного потенціалу, що формується і трансформується в тій чи іншій культурі.

Це все поле культурологічної рефлексії як тоталлогія, як певна тотальність пошуків духовного, формує новий диспозитив, антропологічний вимір культуротворчості, коли людина традиційна протиставляється людині, яка позбавляється традиційного культурного топосу, коли формується новітня реальність - глобальний культурний екосвіт. Так, семіотичний структуралістський підхід, коли все розуміється як текст, як повідомлення, як своєріднитй есенціалістський вимір буття раптом заміщується візуальним поворотом - окуляцентризмом (довірою до реальності, довірою до віртуальних реалій світу, до оптикуму, до оптичної конфігурації людського «я»). До цього доклали багато зусиль новітні візуальні технології, починаючи від кінематографу, відео, а потім вже віртуального простору. Так чи інакше створюється той синтез, що завжди описується як синтез мистецтв, тобто синтез вмінь, майстерності й творчості. Тому такий творчий оаз, де формується надзвичайно гостра ситуація інтеграції (культурної, художньої, антропологічної) потребує не просто адекватного осмислення, але переосмислення як новітнього витоку, новітного синтезу та новітніх реалій, які формуються в контексті глобалізації культури.

Таким чином, діалог та розповсюдження стають тим диспозитивом, який дає можливість визначити синтез мистецтв як культуротворчість. Синтетизм та синкретизм еволюції мистецтва синтезуються як культурноісторична цілісність синхронії та діохронії. Мікроінтервали діохронії описуються в рамках твору мистецтв, а також в рамках культурного часу і простору, в рамках сталого еону або темпоральності художного синтезу, що формуються на початку XX ст. 


\section{Список використаних джерел}

1. Бахтин М. М. Проблемы поетики Достоевского. Москва : Советский писатель, 1963. 363 с.

2. Бахтин М. М. Вопросы литературы и эстетики. Москва : Художественная литература, 1975. 502 с.

3. Библер В.С. От наукоучения - к логике культуры: два филосовских введения в двадцать первый век. Москва : Политиздат, 1990. 413 с.

4. Бочкарева О. В. Диалог с С. П. Дягилевым: Критика искусства и искусства критики. Ярославский педагогический вестник. 1917. №1. С. 317-321.

5. Бычков В. В., Маньковская Н. Б., Иванов В. В. Триалог. Москва : ПрогрессТрадиция, 2012.840 с.

6. Гаевский В. Хореографические портреты. Москва : Артист. Режисер. Театр, 2008. 608 с.

7. Зись А. Я. Теоретические предпосылки синтеза искусств. Взаимодействие и синтез искусств. Ленинград, 1978. С. 5-20.

8. Фаворский В. А. Литературно-теоретическое наследие. Москва : Советский художник, 1988.587 с.

9. Фуко М. Воля к знанию / пер. с фр. О. А. Власовой. Санкт-Петербург : Мир, 2014. 285 c.

\section{References}

Bakhtin, M.M. (1963). Problemy poetiki Dostoevskogo [Problems of Dostoevsky’s poetics]. Moscow: Sovetskii pisatel.

Bakhtin, M.M.(1975). Voprosy literatury i estetiki [Questions on literature and aesthetics]. Moscow: Khudozhestvennaya literatura.

Bibler, V.S. (1990). Ot naukoucheniya - $k$ logike kul'tury: dva filosovskikh vvedeniya $v$ dvadtsat' pervyi vek [From science to the logic of culture: two philosophical introduction to the twenty-first century]. Moscow: Politizdat.

Bochkareva, O.V. (1917). Dialog s S. P. Dyagilevym: Kritika iskusstva i iskusstva kritiki [Dialogue with S. Diaghilev: Criticism of art and art of criticism]. Yaroslavskii pedagogicheskii vestnik, no.1, pp. 317-321.

Bychkov, V.V., Mankovskaya, N.B. and Ivanov, V.V. (2012). Trialog [Trialogue]. Moscow: Progress-Traditsiya.

Favorskiy, V.A. (1988) Literaturno-teoreticheskoye naslediye [Literary theoretical heritage]. Moscow: Sovetskii khudozhnik.

Fuko, M. (2014). Volya $k$ znaniyu [The will to know]. Translated from French by O. A. Vlasovoi. St. Petersburg: Mir.

Gayevskiy, V. (2008). Khoreograficheskiye portrety [Choreographic portraits]. Moscow: Artist. Rezhiser. Teatr.

Zis, A.Ia. (1978). Teoreticheskie predposylki sinteza iskusstv [Theoretical backgrounds of the synthesis of arts]. Vzaimodeistvie $i$ sintez iskusstv. Leningrad, pp. 5-20. 


\title{
SYNTHESIS OF ARTS IN SERGE DIAGHILEV`S SEASONS AS A DIALOGUE OF CULTURES: THE POST-REALITY OF INTERPRETATIVE PARADIGM
}

\author{
Anna Arefieva \\ PhD in Philosophy, \\ ORCID: 0000-0003-4619-9281, anna.arefieva@i.ua, \\ National Pedagogical M. P. Dragomanov University, \\ Kyiv, Ukraine
}

The article analyzes the understanding of culture through the globalization of cultural potential in principle and a peculiar synthesis, synchresis and intentional processes that form the universal cultural and historical potential, which needs its interpretation in art. In this context, the experience of S. Diaghilev's seasons shows the very essence of culture as a dynamic integrity. This image was high not only at the beginning of the 20th century, but also still remains relevant today.

The aim of the study is to determine the interaction between the pieces of art, which were played in S. Diaghilev's seasons as a synthesis of arts and dialogue of cultures.

The study uses the intentional method in order to identify and research the acts of consciousness that are involved in the consideration of S. Diaghilev's reality. In addition, comparative and systematic approaches are used. A comparative approach allows comparing various cultural phenomena, styles and genres, types of arts in the context of their occurrence. The system and polysystemic approaches allows determining the principles of holism (system dominant) and anti-holism (the dominant of the system part) as an opportunity to find phenomena of cultural practices in various system configurations: social, ideological, advertising, virtual, etc.

The scientific novelty lies in the fact that in S. Diaghilev's season the end of the twentieth century - the beginning of the twenty-first century are defined in the context of a certain cultural auto-reflection, as there were events that are now referred to as global. At that time, they were defined as urbanizing, transformative, and integrative. The great sense in this context is that the creative groups were formed on the edge of cultural institutions that formed the newest reality of cultural development.

Conclusions. It is proved that the synthesis of arts is impossible without dialogue of cultures, and dialogue is impossible without synthesis. Culture is in some way an art that is a culture. This deep identity of art with culture suggests that both are reality, if it is associated with the fine potential (aesthetic, ethical, anthropological, etc.), and is characterized as competence, proficiency, art, creativity, which point to the spiritual flow of the humanity potential as a spiritual measurements in its absolute signs.

Keywords: culture; dialogue of cultures; art; synthesis of arts; image; ideal. 


\title{
СИНТЕЗ ИСКУССТВ В СЕЗОНЕ СЕРГЕЯ ДЯГИЛЕВА КАК ДИАЛОГ КУЛЬТУР: ПОСТРЕАЛЬНОСТЬ ИНТЕРПРЕТАТИВНЫХ ПАРАДИГМ
}

\author{
Арефьева Анна Юрьевна
}

Кандидат философских наук, ORCID: 0000-0003-4619-9281, anna.arefieva@i.ua, Национальный педагогический университет имени М. П. Драгоманова, Киев, Украина

В статье анализируется осмысление культуры в рамках глобализации культурного потенциала в целом и своеобразным синтезом, синкрезамы и интенциональными процессами формируют всеобщий культурно-исторический потенциал, нуждается в своей интерпретации в искусстве. В этом контексте опыт сезонов С.Дягилева свидетельствует о самой сути культуры как динамической целостности. Этот образ был приоритетным не только в начале XX в., но и до сих пор остается актуальным.

Целью статьи является определение взаимодействия в художественных произведениях, которые ставились в сезонах С. Дягилева как синтез искусств и диалог культур.

В исследовании использованы интенциональный метод, который позволил выявить и исследовать акты сознания, которые участвуют в осмыслении реальности С.Дягилева. Кроме того, использованы компаративный и системный подходы. Компаративный подход дает возможность провести сравнительный анализ различных феноменов культуры, стилей и жанров, видов искусств в контексте их возникновения. Системный и полисистемный подход дает возможность определить принципы холизма (доминанты системы) и антихолизма (доминанты части системы) как возможность нахождения феноменов культурных практик в различных системных конфигурациях: социальных, идеологических, рекламных, виртуальных и др.

Научная новизна заключается в том, что конец XX - начало XXIв. в сезонах С.Дягилева определены в контексте определенной культурологической авторефлексии, когда века назад возникали события, которые сейчас именуются «глобализационными». В то время они определялись как урбанизационные, трансформативные, интегративные. Огромное значение в этом контексте имеет тот факт, что формировались творческие коллективы на грани культурных институтов, которые создавали новую реальность культуры.

Выводы. Доказано, что синтез искусств невозможен без диалога культур, а диалог невозможен без синтеза. Культура определенным образом является искусством, которое является культурой. Эта глубинная тождественность искусства с культурой свидетельствует о том, что и та, и другая реальность, если ее связывают с изобразительным потенциалом (эстетическим, этическим, антропологическим и др.), характеризуется как умением, мастерством, творчеством, креативностью, свидетельствующими о духовном потоке потенциала человечности как духовного измерения в своих абсолютных признаках.

Ключевые слова: культура; диалог культур; искусство; синтез искусств; образ; идеал. 